\title{
Emissions inventory analysis for an urban (industrial)-rural (agricultural) environment
}

\author{
M. Dios, J. A. Souto \& J. J. Casares \\ Department of Chemical Engineering, \\ Universidade de Santiago de Compostela, Spain
}

\begin{abstract}
The predominant driving forces for improving the quality of life in our society are based on the increased consumption of natural resources and subsequently the production of effluents that result in more and more pressure on the environment. This is especially important in urban environments, which take up about $2 \%$ of the total land surface of Earth, but consume $75 \%$ of the natural resources. (Ensuring quality of life in Europe's cities and towns. EEA Report No.5/2009. European Environment Agency, 2009.) The urban environment depends on resources that are transformed away from their origin whilst effluents tend to affect the neighbouring areas. Therefore, urban areas and the rural areas around them are highly interconnected.
\end{abstract}

The aim of this work is to set up an annual air emission inventory for an urban environment and its surrounding area. The inventory was carried out following EMEP/CORINAIR Emission Inventory Guidebook methodology (EMEP/CORINAIR Emission Inventory Guidebook - 2007. Technical Report No. 16/2007. European Environment Agency EEA, 2007.) An area of 50x50 km² was chosen, including a city of approximately 100000 inhabitants, and 51 rural municipalities around it (30 completely and 21 partially affected). This area matches up with the EMEP $(51,14)$ grid cell (NW of Spain).

The emissions inventory was elaborated considering industrial, residential, commercial, agricultural and transport sectors. All groups of pollutant sources defined by EMEP/CORINAIR were studied. The pollutants considered were CO, $\mathrm{NO}_{\mathrm{x}}, \mathrm{NMVOC}, \mathrm{SO}_{\mathrm{x}}, \mathrm{NH}_{3}$, GHGs, heavy metals and particles.

For all the sectors analyzed, the major contributions to urban emissions were those related to transport (road traffic), residential (domestic heating) and 
industrial; and for rural emissions the most significant emissions were off road machinery and pig and poultry farming. The results obtained are compared with those included in EMEP emissions database. (CEIP EMEP Centre on Emission Inventories and Projections, http://www.ceip.at.) Major differences were encountered for all sectors, but especially in the transport and residential sectors for the urban environment and off road activity for the rural area.

Keywords: emissions inventory, rural area, urban area, EMEP/CORINAIR, off road emissions, transport emissions.

\section{Introduction}

In order to assess emissions impacts, modelling tools are used to simulate the behaviour of emissions to the atmosphere: transport, deposition and/or chemical transformation. All these set up emission influence over final air quality standards. However, the assessment of this influence requires qualitative and quantitative characterization of the emissions, which can be done through emissions inventories. An emissions inventory can be defined as a compilation of data from pollutant sources and every single pollutant emitted. Inventories must be framed within a specific geographic area and temporal scale, as well as specific emission sources and pollutants. The aim of this work will focus on these aspects, taking into account that emissions inventories are always dynamic projects, subject to improvements and enlargements.

Emissions inventories were born as control tools for pollutant reduction policies with the Convention on Long-range Transboundary Air Pollution (CLRTAP) in 1979. As a result of this, other protocols were issued with the purpose of controlling and reducing specific pollutants emissions. CLRTAP also laid the foundation for the 1984 European Monitoring and Evaluation Programme, EMEP, which is based on three mainstays: emission data collection, air quality and meteorological data measurement and pollutants transport and deposition modelling [4]. In 1985, the CORINAIR inventory (CO-oRdination d'Information Enviornmentale) was established; its main objective was the atmospheric emissions estimation of all anthropogenic and natural pollutant sources. Since 1993, the CORINAIR inventory, which was previously developed in parallel to the EMEP Programme, was coupled with the EMEP Programme and together they constitute the EMEP/CORINAIR inventory. As a result of the combination of these two programmes, this inventory includes both calculation and modelling emissions tasks.

The EMEP/CORINAIR methodology [2] allows, in a systematic and attainable way, emission calculation for a wide range of activities. The aim of this work is to obtain detailed information about these activities and their emissions in order to identify the significance of each activity for the urban environment considered and the neighbouring areas. ESRIßARCMAP 9.2 geographic information system was used for the georeferenciation of pollutant sources. 
Activity definition

Definition of pollutant source

Bibliographic compilation

- Split up pollutant sources into basic units [5]

- International codifications: SCC, IPCC, SNAP

- More specific units $\rightarrow$ higher precision

Basic units' identification

- Specific activity and area information: process, activity factors

- Public information: statistical, industrial data

Models and emissions factors compilation

- Calculation models and emissions factors from international sources: EMEP/CORINAIR [2], AP-42 [6], IPCC [7]

\section{Emission calculation}

- Results from the use of compiled information: models, emission factors and activity factors

\section{Validation}

- Comparison with reference data:

- EMEP program [3,4], PRTR [8] (industrial)

Figure 1: $\quad$ Organized emission calculation procedure developed.

\section{Methodology and scope}

\subsection{Emission calculation methodology}

Emission calculation must be understood as a systematic and organized process, which allows estimation of emissions from a specific pollutant source. A general procedure for setting up a bottom-up emissions inventory (figure 1) was developed. Pollutant sources are decomposed into individual units, called basic units, which can be quantified independently, attending to their emissions. The more specific these units; the lower will be the calculation-related error. Correct application of the methodology will guarantee that the estimated values are the best approximation to reality. Inventory validation is required; this was carried out by comparison between the results obtained and reference data: EMEP inventory [3]. 


\subsection{Scope}

The set up of an emissions inventory requires the definition of the scope: about activities, pollutants, temporal scale and geographic area.

\subsubsection{Activities considered}

The EMEP/CORINAIR methodology [2] establish emission calculation procedures for the pollutant sources as follows: combustion in energy and transformation industries, non-industrial combustion plants, combustion in manufacturing industry, production processes, extraction and distribution of fossil fuels, solvent and other product use, road transport, other mobile sources and machinery, waste treatment and disposal and agriculture.

\subsubsection{Pollutants selected}

This study covers the following air pollutants: $\mathrm{CO}, \mathrm{NO}_{\mathrm{x}}, \mathrm{NMVOC}, \mathrm{SO}_{\mathrm{x}}, \mathrm{NH}_{3}$, GHG $\left(\mathrm{CO}_{2}, \mathrm{CH}_{4}, \mathrm{~N}_{2} \mathrm{O}\right.$ ), heavy metals (As, $\mathrm{Cd}, \mathrm{Cu}, \mathrm{Cr}, \mathrm{Hg}, \mathrm{Ni}, \mathrm{Pb}, \mathrm{Zn}$ ) and particles (as $\mathrm{PM}, \mathrm{PM}_{10}$ and $\mathrm{PM}_{2.5}$ ).

\subsubsection{Time horizon}

The base year is 2007, which was the reference year for the gathered EMEP data.

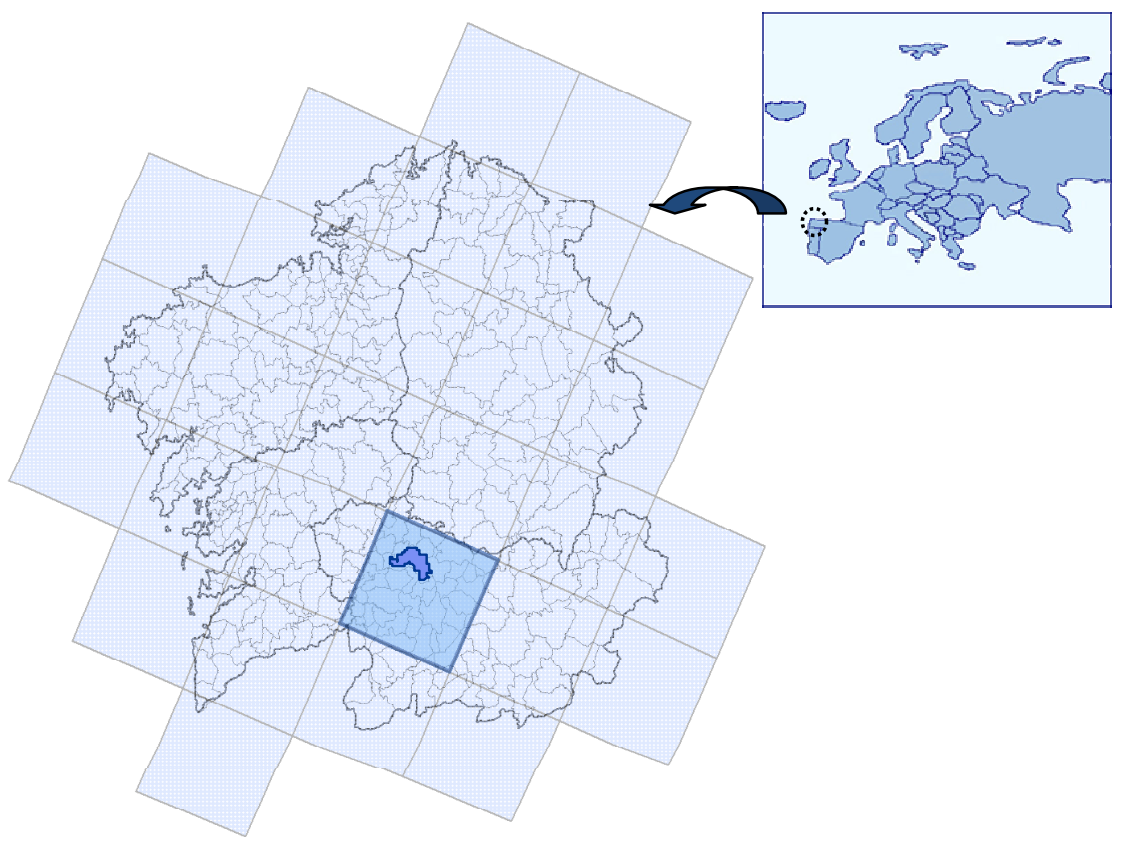

Figure 2: EMEP grid in Galicia-NW of Spain. Highlighted EMEP cell $(51,14)$ and Ourense municipality. 


\subsubsection{Geographic are studied}

The geographic area includes the above-mentioned domain, EMEP $(51,14)$ grid cell (see figure 2). This cell is centred in the city of Ourense, which has slightly more than 100000 inhabitants, and emission sources related to the urban environment can be identified. In neighbouring municipalities, there are hardly significant urban centres, consequently, rural sources, such as agricultural or farming activities are the most significant.

\section{Results and discussion}

\subsection{Overall results}

Application of the methodology described in figure 1 results in the total emission values shown in Table 1 where the main EMEP/CORINAIR headings were indicated by numbers.

Table 1: Emissions obtained in the application of EMEP $(51,14)$ grid cell.

\begin{tabular}{|c|c|c|c|c|c|c|c|c|c|c|c|}
\hline & \multicolumn{11}{|c|}{ EMISSIONS (t/year) } \\
\hline & $\mathrm{NO}_{\mathrm{x}}$ & NMVOC & $\mathrm{CO}$ & $\mathrm{SO}_{\mathrm{x}}$ & $\mathrm{NH}_{3}$ & PM & $\mathrm{PM}_{2.5}$ & $\mathrm{CO}_{2}$ & $\mathrm{CH}_{4}$ & $\mathrm{~N}_{2} \mathrm{O}$ & $\begin{array}{l}\text { Heavy } \\
\text { metals }\end{array}$ \\
\hline 1 & 391 & 4 & 97 & 714 & - & 48 & 27 & 157925 & 14 & 2 & 1 \\
\hline 2 & 119 & 95 & 773 & 195 & 0 & 74 & 67 & 12485 & 40 & 2 & $<1$ \\
\hline 3 & 362 & 10 & 170 & 377 & - & 141 & 57 & 119248 & 17 & 2 & 2 \\
\hline 4 & - & 594 & - & - & 1 & 11256 & - & - & 1 & - & 2 \\
\hline 5 & - & 57 & - & - & - & - & - & 1 & 44 & - & - \\
\hline 6 & - & 1503 & - & - & - & - & - & - & - & - & - \\
\hline 7 & 4731 & 971 & 6709 & 5 & 48 & 715 & 332 & 750304 & 77 & 28 & 1 \\
\hline 8 & 2855 & 407 & 1023 & 28 & $<1$ & 252 & 254 & 45508 & 10 & 67 & $<1$ \\
\hline 9 & 6 & 73 & 1 & $<1$ & 53 & $<1$ & - & 11101 & 1184 & 0 & $<1$ \\
\hline 10 & 35 & - & - & - & 1114 & - & - & - & 611 & 672 & - \\
\hline$\Sigma$ & 8499 & 3713 & 8772 & 1320 & 1216 & 12487 & 738 & 1096572 & 1997 & 773 & 5 \\
\hline
\end{tabular}

1-Combustion in energy and transformation industries, 2-Non-industrial combustion plants, 3-Combustion in manufacturing industry, 4-Production processes, 5-Extraction and distribution of fossil fuels, 6-Solvent and other product use, 7-Road transport, 8-Other mobile sources and machinery, 9-Waste treatment and disposal and 10-Agriculture [2].

The analysis of the results can be summarised as follows:

- Combustion processes play a significant role in emissions of some pollutants, like $\mathrm{SO}_{\mathrm{x}}$ and heavy metals. They are responsible for more than $49 \%$ of the total heavy metal emissions.

- Emissions due to road transport are very important in traditional "transport" pollutants, $\mathrm{NO}_{\mathrm{x}}, \mathrm{CO}$, particles and $\mathrm{CO}_{2}$ [9]. In Ourense city there are some stretches of the road with traffic density values of 34000 vehicles per day. Apart from conventional traffic, the study area is 
crossed by a highway with a stretch 85 kilometres along the area under study and has traffic density values over 18000 vehicles per day and carries a significant portion of heavy traffic (18\% of the total traffic) $[10,11]$.

- Attending to off-road transport and machinery, it is important to highlight the contributions of the use of agricultural and forestry machinery, like tractors and harvesters. The study area has more than 11000 forestry and agricultural, vehicles registered $[12,13]$.

It is also important the role of the farming industry. Within the area, 11 pig and 5 poultry farms were identified, with more than 35000 pigs and 1090000 poultry, respectively [8] and a major slaughterhouse and egg and poultry factory.

\subsection{Comparison with EMEP data}

The coherence of the obtained results was verified, by comparing them with the EMEP inventory. This comparison allows a qualitative evaluation of its accuracy related to every one of the pollutant sources, and also to identify those aspects that can be improved. However, the EMEP inventory do not cover all the pollutants included in this study, so the comparison is limited to $\mathrm{NO}_{\mathrm{x}}$, NMVOC, $\mathrm{CO}, \mathrm{PM} 2.5, \mathrm{SO}_{\mathrm{x}}, \mathrm{NH}_{3}, \mathrm{Cd}, \mathrm{Hg}$ and $\mathrm{Pb}$.

\subsubsection{General comparison between inventories}

In figure 3, the disparities between EMEP and the experimental inventory are presented, with EMEP assigned a value of 1 . Values close to 1 will prove the coherence of both inventories.

Figure 3 shows the general evaluation for the different pollutants: the results obtained are comparable since inventories data are of the same order of magnitude; however important differences are observed. These differences are mainly due to the specific characteristic of study area, as it is explained in the following sections.

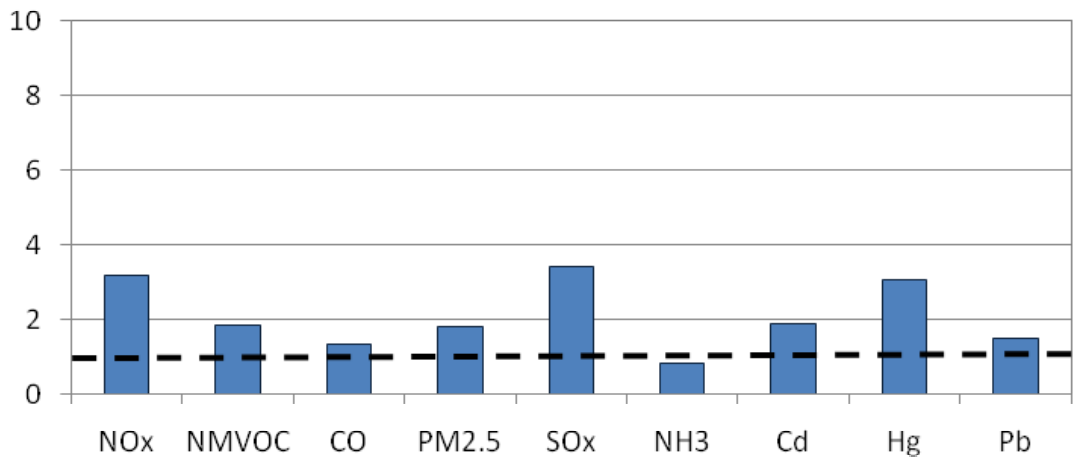

Figure 3: Inventories comparison: ratio between global emissions from experimental inventory and EMEP inventory. 


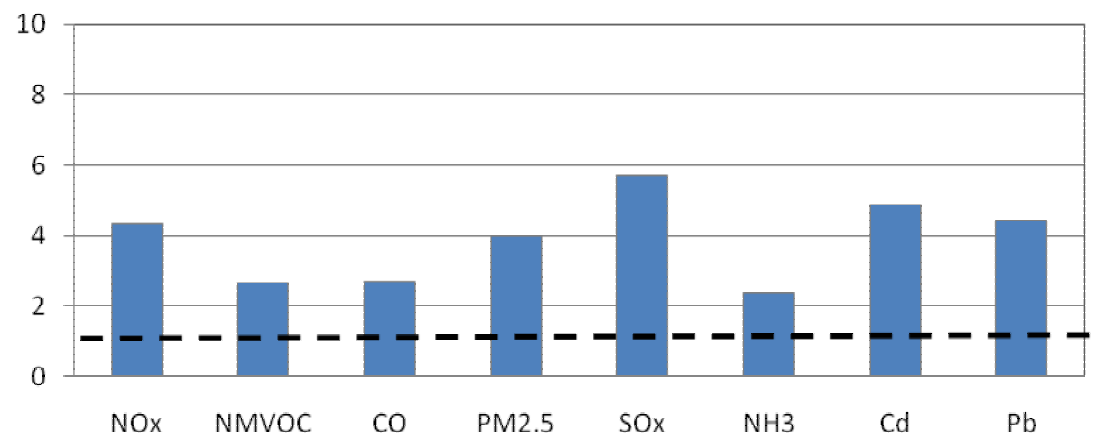

Figure 4: Inventories comparison: ratio between road traffic emissions for experimental inventory and EMEP inventory for $\mathrm{NO}_{\mathrm{x}}, \mathrm{NMVOC}$, $\mathrm{CO}, \mathrm{PM} 2.5, \mathrm{SO}_{\mathrm{x}}, \mathrm{NH}_{3}, \mathrm{Cd}, \mathrm{Pb}$.

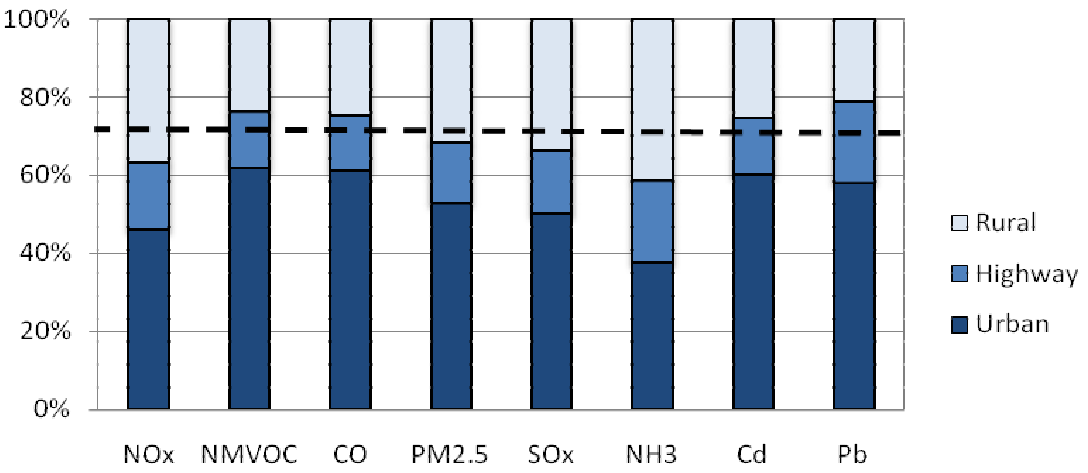

Figure 5: Contribution of urban, highway and rural driving modes in road traffic emissions of experimental inventory.

\subsubsection{Road transport}

The same considerations as those made in a previous paragraph (overall comparison) are to be drawn in general. As can be observed in figure 4, emissions obtained are higher than the reference data provided by the EMEP inventory for $\mathrm{NO}_{\mathrm{x}}, \mathrm{PM} 2.5, \mathrm{SO}_{\mathrm{x}}, \mathrm{Cd}$ and $\mathrm{Pb}$.

$\mathrm{SO}_{\mathrm{x}}$ emissions must be taken carefully, because they are based on maximum sulphur content in fuels due to legal specifications for Spain in 2007. Therefore, these emissions are slightly overestimated. Cd emissions provided by EMEP are quite low; consequently the differences obtained are not very significant.

The two major characteristics for these differences between experimental vs. EMEP emissions are the high percentage of urban driving habits and the highway contributions in the experimental inventory. As it is shown on figure 5, contributions from urban and highway driving represent an average percentage of 53.3 and $16.7 \%$ respectively, in comparison to rural driving, which only reaches $30 \%$; although only pollutants considered by EMEP were taken for evaluation purposes, similar percentages are found for the other pollutants. 
These results are very significant; the basic reason being the fact that only one municipality exceeds 100000 inhabitants, and all the others are one order of magnitude or more, less populated.

\subsubsection{Residential sectors}

Again, the same considerations as the overall comparison were taken into account. In this case, differences of several magnitude orders were encountered for some heavy metals emissions (Figure 6). These differences can be explained because EMEP data for heavy metals for residential sectors are really low: 0.08 $\mathrm{kg} /$ year for $\mathrm{Cd}, 0.05 \mathrm{~kg} /$ year for $\mathrm{Hg}$ and $0.24 \mathrm{~kg} /$ year for $\mathrm{Pb}$. For the other pollutants, experimental inventory data and EMEP inventory show coherency.

Domestic heating represents a very significant percentage on these emissions. In the study area, major contributions are due to heating devices which use gasoil, as a result of the poorly developed natural gas network in that area. Approximately $30 \%$ of residential buildings use this fuel $[12,13]$.

\subsubsection{Off road activity}

As it is shown on figure 7, experimental inventory data are higher than EMEP inventory data; even for some pollutants (NMVOC, $\mathrm{CO}, \mathrm{NH}_{3}$ and $\mathrm{Pb}$ ) they are more than four times bigger.

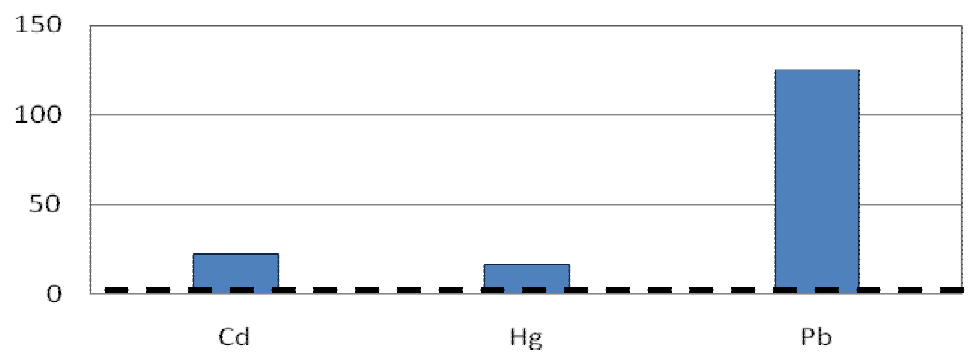

Figure 6: Inventories comparison: ratio between residential sector emissions for experimental inventory and EMEP inventory for heavy metals.

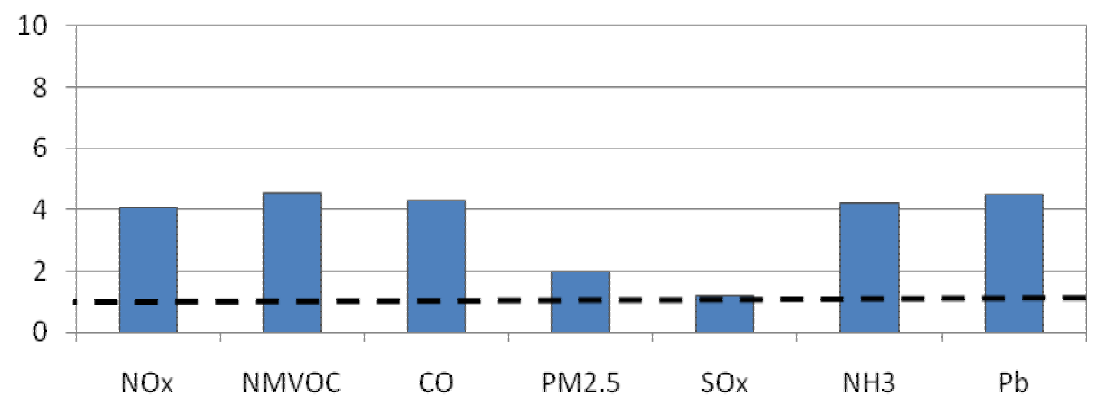

Figure 7: Inventories comparison: ratio between off road activity emissions for experimental inventory and EMEP inventory for $\mathrm{NO}_{\mathrm{x}}$, NMVOC, CO, PM2.5, $\mathrm{SO}_{x}, \mathrm{NH}_{3}$ and $\mathrm{Pb}$. 


\section{Concluding remarks}

The present work includes all those emissions sources which, because of its magnitude or significance, generate high atmospheric pollution over EMEP $(51,14)$ grid cell. Emissions were estimated through an organized calculation procedure, based on compilation of specific data of the activities, and also bibliographic data. From the results obtained, the following conclusions can be drawn:

The setting up of an emission inventory requires the application of simplifications and mathematical models and factors for the establishment of their emissions. For practical reasons, it is not possible to have measured data on emissions of all pollutants in pollutant sources. Regarding this subject, and because of the application of internationally accepted information sources, estimated emission values are just one hierarchical level below measured emission data.

The experimental inventory reflects specific characteristics of $\operatorname{EMEP}(51,14)$ grid cell, which are not found in EMEP inventory data:

- The contribution of the traffic, and particularly urban and highway traffic, lead to major differences between inventories, especially for the following pollutants: $\mathrm{NO}_{\mathrm{x}}, \mathrm{PM} 2.5$ and $\mathrm{Pb}$.

- Significant differences were encountered between experimental data and EMEP inventory for heavy metals in residential sectors. Despite these differences, it is important to highlight the low values in the EMEP inventory for heavy metals in residential sector.

- Contribution of agricultural and forestry activity is reflect on major differences encountered between experimental inventory and EMEP data.

A bottom-up approach for emissions inventories improves the accuracy of the emissions calculated, because emissions factors are applied to particular units for which specific information is available. This is probably the hardest part of the work where establishing an emissions inventory, but future application of the results obtained completely justifies all the efforts made.

\section{References}

[1] Ensuring quality of life in Europe's cities and towns. EEA Report No.5/2009. European Environment Agency, 2009.

[2] EMEP/CORINAIR Emission Inventory Guidebook - 2007. Technical Report No. 16/2007. European Environment Agency EEA, 2007.

[3] CEIP EMEP Centre on Emission Inventories and Projections, http://www.ceip.at

[4] Convention on Long-range Transboundary Air Pollution Steering Body to the Cooperative Programme for Monitoring and Evaluation of the Longrange Transmission of Air Pollutants in Europe (EMEP). United Nations Economic Commission for Europe UNECE http://www.unece.org/env/ lrtap/emep/welcome.html 
[5] Casares J.J. et al. Inventory, Assessment and Projection of Galician atmospheric industrial emissions. University of Santiago de Compostela. Spain, 2005 (in Spanish).

[6] AP-42 Compilation of Air Pollutant Emission Factors. Volume I, Stationary Point and Area Sources. Fifth Edition. U.S. Environmental Protection Agency U.S. EPA.

[7] IPCC Guidelines for National Greenhouse Gas Inventories. National Greenhouse Gas Inventories Programme. 2006

[8] Spanish Government. PRTR-Spain: European Pollutant Release and Transfer Register for Spain. Department of Environment. Spain, 2008 http://www.prtr-es.es

[9] Computer Programme to calculate emissions from road transport COPERT (Version 4). Methodology and emission factors. European Environment Agency EEA, 2009.

[10] Galician Government. Traffic report about Galician roads 2007. Department of territorial policy, public works and transport. Xunta de Galicia. Spain, 2008.

[11] Spanish Government. Statistics in national fleet of vehicles. Public Department in charge of traffic (DGT). www.dgt.es

[12] INE (Spanish Statistical Institute) http://www.ine.es/

[13] IGE (Galician Statistical Institute) http://www.ige.eu/ 